\title{
8
}

\section{The Political Ramifications of Papua New Guinea's Commission of Inquiry}

\section{Colin Filer with John Numapo}

\section{Introduction}

The circumstances surrounding the establishment of the Commission of Inquiry (COI) into special agricultural and business leases (SABLs) in Papua New Guinea (PNG) have already been described in Chapter 6. This chapter deals with the political ramifications of the findings and recommendations that were officially published at the end of 2013, and explores some of the factors responsible for the length of time that it took for the Commission to finish its work, and the length of time that it has since taken for the PNG government to produce a coherent response.

This chapter has two main parts. The first part contains an interview that I (Colin Filer) conducted with Chief Commissioner John Numapo in April 2014, six months after the public release of his final report. ${ }^{1}$ The interview was conducted by email correspondence between the two of us. At that juncture, John had been contracted by the Australian aid program to strengthen the magisterial services of Solomon Islands, and 
was therefore resident in Honiara. His responses to my questions are printed in italics. These responses have only been edited for the sake of stylistic consistency with the rest of the chapter. I have added occasional footnotes to his responses to clarify or query the significance of some of his statements. John has no responsibility for any of the other statements made in this chapter.

The second part of the chapter consists of an account of some of the more significant actions, decisions and arguments that have taken place since this interview was conducted, and that cast some light on the PNG government's response to the recommendations made in John's report and that of his fellow commissioner, Nicholas Mirou. This shows that there is no clear direction to the policy process in which the COI was embedded, and leads to some rather depressing conclusions about the rule of law in PNG.

\section{An Interview with John Numapo, April 2014}

\section{COLIN:}

Can you tell us what factors delayed the tabling of the Commission's final reports in the national parliament for a period of 18 months after the Commission completed its hearings in March 2012?

\section{JOHN:}

Let me start by giving you some background to the whole inquiry itself and how we structured it. The COI adopted a 'four-phased' approach in this SABL inquiry. The first phase was the start of the inquiry in which we focused mainly on receiving preliminary evidence from the principal agencies of government responsible for the management and administration of SABLs. They included the Department of Lands and Physical Planning; the Department of Agriculture and Livestock; the Department of Environment and Conservation; the PNG Forest Authority; and the PNG Investment Promotion Authority. We also received evidence relating to the legislative and policy frameworks that govern the grant of SABLs. The second phase involved provincial hearings whereby the COI was divided into three teams headed by a commissioner and dispatched to the provinces where the SABLs were located to conduct on-site hearings as well as inspecting the actual SABL sites. Phase three was the final hearing conducted by the commissioners separately or 
jointly as appropriate to consolidate and adjust evidence gathered during both the preliminary hearings and the provincial hearings. The fourth and final phase involved the final submissions by counsels assisting the inquiry and the write-up of the final reports by the commissioners.

Phases 2 and 3 activities were disrupted by funding issues, lack of resources and other critical intervening factors that affected the inquiry. The 2012 national elections, the political in-fighting, the change of government, the lock-down of the Government Printing Office that housed the COI and the 'threat' by the new in-coming government to stop the $S A B L$ inquiry were some events that directly affected the inquiry. The COI was virtually locked out of the building during the political impasse. ${ }^{2}$ This created a lot anxiety and uncertainties amongst the members of the COI. The interruptions went on for weeks. Delays in funding support resulted in personnel engaged by the COI not being paid for months, resulting in people not turning up for work. In fact, the government still owes the commissioners and members of the legal and technical teams 15 months of unpaid allowances and salaries that are still yet to be paid to this day. The delay in the production of the recorded transcripts to assist the commissioners with their final write-ups, and the lack of cooperation and display of arrogance by certain members of the COI, also affected the completion of the final reports by the given deadline. Certain factors that contributed towards the delay were totally beyond our control and were not of our making.

Due to the above factors, I then wrote to the Chief Secretary and the Prime Minister seeking extension of time to submit the final reports. The Prime Minister granted us an extension to the end of June 2013. With respect to the delay in presenting the final reports to Parliament, this is a matter entirely within the jurisdiction of the Prime Minister and Cabinet and I cannot comment on that. What I can say is that we have delivered the final reports by the given deadline. The final reports were submitted to the government on 26 June 2013.

2 John appears to be referring to the constitutional crisis that occurred in December 2011, when the Supreme Court ruled that the parliamentary vote by which Peter O'Neill had replaced Michael Somare as Prime Minister had been unconstitutional. This produced a standoff that lasted for several weeks as each man tried to assert his legal authority over the executive arm of the state. O'Neill won this battle because he retained his parliamentary majority, but the authority of the Supreme Court was seriously weakened. 


\section{COLIN:}

To what extent do you think that the failure of one of the three commissioners to submit his own final report has made it difficult for the government to implement the Commission's recommendations? What is to be done about the 30 or more leases which Commissioner Jerewai investigated, given that his recommendations are not available to the government?

\section{JOHN:}

Apart from the delay in submitting the final reports, as alluded to above, Commissioner Alois Jerewai's failure to submit his final report is the biggest set-back to what could have been a very successful inquiry. Commissioner Jerewai blamed lack of funding as a reason for not submitting his report, which I think is an absolute nonsense. If Commissioner Nicholas Mirou and I can complete our final reports, despite financial diffculties, surely Jerewai could have done the same.

Failure by one commissioner to submit his final report should not be an excuse for the government not to implement the findings and recommendations of the two other commissioners. There are two things the government can do under the circumstances. First, appoint a commissioner to conduct a fresh inquiry into the 30 or so SABLs, especially in East and West New Britain provinces and Gulf Province. Secondly, drawing some general conclusions from the findings of the two final reports, the government could assume that the 30 or so leases were also unlawfully issued, like the majority of the other $S A B L$ s around the country, and therefore should be revoked. However, this presumption is risky and the government may have to carefully consider that.

\section{COLIN:}

At the beginning of your own final report, you recommended 'that the current SABL setup be done away entirely' (Numapo 2013: 4), but towards the end, you recommended that special agricultural and business leases should 'be retained ... [as] a national development and customary landowner empowerment mechanism' (ibid.: 255). In his statement to Parliament in September 2013, the Prime Minister himself expressed some surprise that you had recommended retention of the 'SABL setup' after finding that only four of the leases investigated by yourself and Commissioner Mirou had genuine landowner consent. Can you explain this apparent contradiction in your recommendations? 


\section{JOHN:}

The overall recommendation of the COI is that the current SABL setup is a complete failure and must be abolished. The current setup is riddled with loopholes, shortfalls and inadequacies—so much so that corrupt public officials and unscrupulous individuals are taking advantage of it to enrich themselves. There is simply no transparency and accountability in the whole process, starting from application to processing to the final issuing of SABLs. Although well intended, the $S A B L$ concept has lost its meaning over time and is no longer serving the purpose for which it was set. The SABL scheme was conceived as an empowerment option for customary landowners that would facilitate economic opportunities for landowners. It has lost its focus over time as a system and a process to offer financial incentives to the landowners and at the same time protect their interests over their land.

What I am trying to say on page 255 is that SABL as a 'concept' (not necessarily the SABL itself) is good and should be continued in some form (other than the current setup) as it is all about empowering landowners to participate meaningfully in the economic development of the country by freeing up their customary land through the lease-leaseback scheme. Ninety-five per cent of the land in PNG is tied up under customary ownership, and unless that is unlocked, there will be very little in terms of real progress and development. The SABL scheme was introduced because of the long delay in the introduction of customary land registration and the tenure conversion of customary land. Customary land registration was vigorously opposed by the people for fear of losing their land outright. Tenure converted land was subject to very strict limitations which discouraged banks and other lenders from lending money using land as security. The SABL concept seems to provide a good guarantee for the banks (Numapo 2013: 9). It is for this reason that I am suggesting that whilst the concept (lease-leaseback) is good, the abuse and hijack of the current $S A B L$ setup has grossly tarnished the integrity of what was once a noble and well-intended concept to allow landowners to partner government in national development through the use of their customary land whilst retaining residual rights to usage and ownership. The time is now ripe for introduction of another viable alternative mechanism that is risk-free, robust, transparent, and landowner friendly.

3 This is a reference to the Land (Tenure Conversion) Act that dates from the period of Australian colonial administration and allows for the conversion of customary land to individual freehold titles. Very little use has been made of this legislation, and the National Land Development Taskforce recommended that it be repealed (GoPNG 2007: 96). 


\section{COLIN:}

At the beginning of your final report (Numapo 2013: 5), you also talk about the need for a 'policy platform [that] will set the foundation for harmonizing the legal framework and pave the way for the State to access customary land in a non-threatening and landowner friendly way'. At the end of your report (ibid.: 261), you call this a 'National Land Policy Harmonization exercise'. What do you think is the single most essential ingredient of such a policy platform?

\section{JOHN:}

The policy platform is first and foremost intended to safeguard and protect the interests of the landowners and also to make sure that customary land is not totally alienated under the various acquisition schemes. The current piecemeal and ad hoc approach to acquiring customary land has caused more harm than good because of the different laws and policies that govern it. We hope that the 'harmonisation of laws' and 'standardisation of practice' will bring about some degree of consistency, clarity, parity and regularity in the various land acquisition processes. The policy will provide the basis for streamlining, harmonising and synchronising the various different practices and procedures on 'acquisition of customary land by agreement' for economic development, as in the case of SABLs (under Sections 11 and 102 of the Land Act 1996) and 'compulsory acquisition' of customary land (under Section 12) for national development purposes that are currently managed under different schemes and governed by separate legislations and policies. A number of land acquisition schemes were introduced over the years for 'specific purposes' regulated by different sets of rules and guidelines. Legislative and policy frameworks were done on a piecemeal basis and were, in most cases, ad hoc. Consequently, many land acquisition schemes were created with no proper oversight and control by the relevant agencies of government, resulting in abuses and manipulations by corrupt government officials and unscrupulous foreigners. We believe that, by harmonising the laws and standardising the practices, we will remove ambiguities and generality in the laws and practices. The outcome will then inform the National Land Policy as part of the overall reforms going forward.

\section{COLIN:}

At the end of your report (Numapo 2013: 264), you say that special agricultural and business leases should be reserved for so-called 'high-impact' projects that need large areas of land. But, by my calculation, 98 per cent of the land that has been covered by such leases since 1996 
has been devoted to projects with a size of more than 10,000 hectares, which their supporters would all probably describe as 'high-impact' projects. So how do you expect the process of acquiring customary land for projects of this kind to be different and better in future?

\section{JOHN:}

Let me put some background to it before I attempt to answer the question. There are two types of permission to clear forests. Type 1 is the timber authority issued by Provincial Forest Management Committees to carry out 'small scale agriculture projects' or other land use pursuant to Section 87 of the Forestry Act 1991. Type 2 is the forest clearing authority (FCA) to undertake large scale forest clearance' issued by the National Forest Board (NFB) pursuant to Sections 90A, 90B, 90C and 90D of the Forestry Act. For SABL purposes, the FCA applies in most cases. Sections $90 A$ and $90 B$ deal with large-scale conversion of forest for agriculture and other land use, whilst $90 \mathrm{C}$ and $90 \mathrm{D}$ deal with large-scale conversion of forest for major road construction projects. These are sometimes referred to as 'high-impact' projects.

The Forestry Act requires forest clearance (clear felling) for SABL purposes to be limited to 500 hectares initially on application. This is to ensure that planned agriculture projects are commenced on the initial 500 hectares before the developer moves on to the next 500 hectares. The developer is required to apply to increase the number of hectares, and based on proper assessment and technical advice provided by the Department of Agriculture and Livestock (DAL), the NFB may increase it up to 5,000 hectares. However, in many instances we found that the developers and FCA holders are carrying out 'clear felling' well outside of the 500 hectares covered by their FCA. This is outright illegal and a direct breach of Section 90A of the Forestry Act. DAL has been allowing that clearance to go beyond the required 500 hectares for 'practical purposes' until the maximum land required for the agriculture project is cleared instead of stop-start for every 500 hectares. In addition, the developers are allowed to sell logs of merchantable value to 'raise capital' for the agriculture component. Again, this is unlawful as developers must have sufficient starting capital before getting an SABL in the first place.

To answer the question: yes it is true that the majority of the land that has been acquired is in SABLs that are over 10,000 hectares, and most of these are referred to as 'high-impact' projects because they not only involve large areas of land, but are often associated with large-scale agriculture projects or road line projects that impact on the people and the immediate environment. 
The practice to increase the hectares is currently condoned and promoted by $D A L$ and the PNG Forest Authority despite the fact it is unlawful. DAL considers that to be a more 'realistic and practical' approach for agriculture projects as they require land of more than 10,000 hectares. The fact of the matter is that this practice will no doubt continue into the future as it is considered to be a more viable option and an attraction to current and potential investors. What we need to do right now is to properly distinguish between large-scale and small-scale forest clearance permits and introduce different monitoring guidelines for different types of permit to avoid applying the same rules for the two as their impacts are different. This also applies to lease conditions and the types of benefits, royalties and compensation that are paid to the landowners. Those operating large-scale agriculture projects should pay more in consideration of the area of land obtained under the $S A B L$, and should be more accountable under a set of stringent guidelines to ensure that they develop the agriculture projects as required under the terms of the lease and not use it as a pretext for logging operations.

There are currently no FCA monitoring guidelines nor an oversight committee to monitor the FCAs that are issued. It is for this reason that we recommend $D A L$ to implement as a matter of priority the recommendations of the National Agriculture Council to develop proper FCA Project Approval and Monitoring Guidelines and to establish an oversight committee to monitor all FCAs and ensure that they comply with the guidelines and the requirements of the law. Oversight and monitoring of the FCAs is seriously lacking at the present time.

\section{COLIN:}

Some senior public servants have been saying that the government is afraid to revoke those leases under which subleases have been granted to foreign investors because of the risk that these investors will sue the government for compensation and the courts will grant their claims. How would you assess the validity of this argument?

\section{JOHN:}

I am not surprised at all to hear this. Two separate incidents happened during the course of the inquiry. First, I was approached by a very senior minister of the current government to carefully consider the ramifications of revoking the SABLs that were issued to foreign investors because of the possibility of legal action against the State for compensation due to loss of business. The second incident involved yet another senior minister of the current government telling me in no uncertain terms that the final reports of the inquiry will not see the 
light of day and will be swept under the carpet. He went on to say that my commissioners and I are wasting our time conducting the inquiry and writing up the reports as it will not be tabled in Parliament and the government has engaged a Queen's Counsel from Australia to go to court to stop the inquiry. I told the two senior ministers that I and my commissioners have a duty to do as required by our terms of reference, and we would continue with the inquiry and deliver the final reports containing our findings and recommendations as we owe it to the people of PNG (especially the customary landowners) to do so. No amount of pressure or threats would deter us from delivering the reports.

Putting one and one together, this is probably the reason why the following things happened:

1. The Prime Minister went public and threatened to refer me and my other two commissioners to the Fraud Squad to investigate us (for what reasons we do not know to this day).

2. There was delay in his tabling of the final reports in Parliament despite the fact that the reports were already submitted to him two months previously (minus Jerewai's report).

3. There was criticism of the final reports and misleading of Parliament on the findings and recommendations of the COI.

4. There was refusal to pay 15 months' worth of salaries owed to the commissioners and other COI staff.

The findings of the inquiry are very clear, including the recommendations. Over 95 per cent of the SABLs were unlawfully issued and must be revoked. They cannot lawfully stand in law. Foreign investors, politicians and corrupt public officials have all conspired and colluded to create bad leases and titles over customary land, as was discovered during the inquiry. They are all equally liable and should be investigated and prosecuted as some of them have been named in the reports. The government has no choice but to revoke the SABLs that were illegally issued, as has been recommended. The issue of compensation is a different matter altogether, and should not be used as an excuse not to implement the recommendations of the COI. The threat of compensation claims against the government is yet another excuse not to implement the recommendations. 


\section{COLIN:}

In March 2011, I wrote a brief for the PNG Department of Environment and Conservation in which I identified eight current government ministers and several other members of parliament who appeared to have vested interests in the grant of SABLs in their own electorates. The current makeup of the national parliament does not seem to be all that different. Given the extent of these vested interests, why do you think the government set up the COI in the first place, and what makes you think that there is enough political will to implement its recommendations?

\section{JOHN:}

It's all about 'political correctness' I guess. The setting up of the COI was a reaction to the public outcry over the manner in which SABLs were issued for dubious agriculture and business purposes and instead used as a licence for full-scale logging operations over large virgin forest tracts. It attracted international attention following the James Cook University conference in March of 2011. The government had to act quickly to 'save face' and it decided to set up the COI. For the politicians and those in government there was a lot at stake. It's all about balancing the competing interests of foreign investors on the one hand and landowners on the other. It is common knowledge that some political parties are funded by foreign investors, particularly those involved in logging operations in the country. Many of the SABLs were initiated and driven by politicians as part of 'bringing development' into their electorates. There was evidence of political pressure, influence and interference in the granting of SABLs. This went up as far as the Prime Minister, as in the case of Bewani (Portion 160C in West Sepik Province) and Changhae Tapioka (Portions 519C, 444C, 446C, 517C, 518C, 521C and 520C in Central Province).

Despite the assurances from Prime Minister Peter O'Neill that the recommendations of the COI will be fully implemented, no action has been taken to date to revoke the SABLs that were unlawfully issued, as recommended by the COI. I do not know how long it will take to implement the recommendations as the landowners are already tired of waiting. I think the government is trying to buy time until people forget about it (unfortunately, this is becoming a trend now in $P N G$ ).

I have my own doubts about the genuineness of the government's promise to revoke the unlawfully issued SABLs. There is too much at stake, and given the current political make-up and the fact that many of those who were named 
in the reports are part of the current government, it will be a difficult task for the Prime Minister to live up to his word to revoke the unlawfully issued SABLs. And based on that, I do not know if there is enough political will to implement the recommendations. I doubt it.

\section{COLIN:}

At one point in your final report (Numapo 2013: 236), you said that the Commission 'received evidence of undue "political pressures" being put on government officials by senior ministers and politicians to fast-track SABL applications and issue titles'. You gave a couple of examples of such pressures being applied. However, I wonder if you felt constrained by your terms of reference from telling a more detailed story about the extent to which such pressures were driving public servants to neglect their duties.

\section{JOHN:}

I am reluctant to go into any more details than what I have already stated in the report, as this might be the subject of another investigation to be carried out in the future, and as we have recommended for such to take place. I do not want to pre-empt or speculate on anything at this point in time. There may also be legal implications. The only thing I can say is that the evidence we received during the inquiry suggests that pressure was applied to government officials to short-cut the processes and procedures to issue SABLs. Threats were issued to sack them if they failed to act, and promises of promotion and a 'good life' were also made. I will stop there.

\section{COLIN:}

In September 2013, Prime Minister Peter O’Neill announced that the Minister for Lands would appoint a task force to establish a new legal framework to protect the interests of customary landowners. In February 2014, he said that the ministers of lands, forests and agriculture would oversee the process of cancelling the leases that were acquired illegally. Nothing more has been said in public about the way this process is being organised. How do you think it should be organised?

\section{JOHN:}

This is totally absurd and ridiculous. It defies logic and does not make any sense at all. These are the very people who screwed up the SABL scheme in the first place. The whole SABL process was hijacked and mismanaged under their watch. I am at a loss to understand why the ministers for lands, forestry 
and agriculture have been given the task to implement the recommendations of the COI when it was their respective departments that were responsible for the management and administration of $S A B L s$, and that messed up the whole $S A B L$ scheme. Adverse findings were made against these government agencies, including their respective ministers, so how on earth do we expect them to effectively implement the recommendations of the COI? The Prime Minister must re-think the composition of the task force and appoint some independent individuals and entities to implement the recommendations.

I wrote to the Prime Minister when presenting my final report and suggested to him that an independent body such as the National Land Development Program (NLDP) be given the task to study the recommendations of the $C O I$ and advise the government on how to implement the recommendations, including the cancellation of the illegally issued SABLs. The NLDP is a multigovernment entity made up of representatives from other government agencies, but also including civil society, facilitated by the National Research Institute. It was set up five years ago to initiate some reforms across the board on land management and administration generally, including acquisitions through the various processes. The NLDP has made some headway on some reforms in recent times and is currently ongoing. I made some references to the NLDP towards the end of my final report (Numapo 2013: 262-3).

\section{COLIN:}

During the course of the Commission's hearings, you and the other commissioners were sometimes at pains to point out that you were not pursuing an agenda set by local or international environmental nongovernmental organisations (NGOs) or 'greenies'. Do you think that the extent of lobbying by these groups could actually be giving the government an excuse to ignore the Commission's recommendations?

\section{JOHN:}

I would say 'yes' but I think it would be one of the many reasons why the government would ignore the recommendations or will be slow at implementing them. The SABL scandal has no doubt put PNG on the world map, with $N G O s$ and greenies all over the world criticising the PNG government for the abuse that is going on and not doing anything to stop it. It is a big agenda, especially in the context of global warming and carbon pollution. 
During the course of the inquiry we received a lot of requests from NGOs and greenies to make representations at the inquiry and give evidence. Unfortunately, our terms of reference did not allow for that as the inquiry was more focused on landowners and government agencies that were expected to appear and give evidence. We did not have the discretion to invite the public at large, and also time was not on our side. NGOs and others have had a field day in pre-empting the outcome of the inquiry, using social media to discuss specific SABLs and the corrupt activities that went on. One of the dailies (the Post-Courier) had a field day by publishing the views of NGOs and the greenies nearly seven days a week when the inquiry was still running, prompting Rimbunan Hijau (owners of the other daily, The National) to threaten to take the Post-Courier to court for defamation and for pre-empting the outcome of the inquiry whilst it was still going on. ${ }^{4}$ It was a real circus, and it could have affected us one way or the other, as those of us involved in the COI also read papers and access social media sites. That is why we were at pains to explain that, despite the writings and the newspaper articles, we were not influenced one way or the other, as we have restricted ourselves to making our findings based on the evidence before us, as adduced through the formal hearings of the inquiry. I am glad to say that the final reports reflected the kind of findings one would have expected, based on the evidence presented to the inquiry. Evidence given before the inquiry was on oath and was subjected to the usual examination in accordance with the rules of evidence.

\section{COLIN:}

Some people have argued that amendments recently made to the Land Groups Incorporation Act and the Land Registration Act, which make it possible for incorporated land groups to directly register titles to their customary land and then grant subleases to investors, make the whole of the 'lease-leaseback scheme' redundant, so all reference to special agricultural and business leases should simply be removed from the Land Act. What are your thoughts on this subject?

\section{JOHN:}

I disagree. The recent introduction of the Land Groups Incorporation Act and the Land Registration Act is a policy initiative of the government to give the landowners the option to voluntarily register titles to their customary land

4 This is a reference to the Greenpeace campaign against the Sigite-Mukus project in East New Britain Province (see Chapters 6 and 7, this volume). 
so that the issue of titles is clearly settled before the granting of a sublease, whether it be for an SABL or for other purposes. However, it is not clear if this will replace altogether the 'lease-leaseback' scheme and make it redundant. The option to voluntarily register the title must interface with the concept of the SABL regime so that the lease-leaseback scheme can continue for large-scale, high-impact, intensive land-based development, as I alluded to earlier. Voluntary land registration is best suited as a landowner empowerment option for more general land use (Numapo 2013: 262). Removing the SABL scheme from the Land Act, and replacing it entirely with a new scheme that is untested, is too risky. The SABL as a concept offers opportunities to customary landowners to participate in economic development through a lease-leaseback arrangement, which in itself already guarantees the return of the land after the term of the project has lapsed. The title reverts back to the customary landowners, and that in itself is a form of security. The area that needs to be looked at is the reduction of the lease period from 99 years to something like 50 years as the maximum period for the lease.

\section{COLIN:}

In a number of cases investigated by the Commission, it turned out that the landowners opposing the grant of leases to one particular landowner company and its preferred foreign investor were mainly interested in having the leases granted to a different landowner company and another foreign investor. In some cases, you suggested that the competing factions should just sit down, sort out their differences, and come up with a plan on which both sides could agree. As a former chief magistrate, what is your view of the local-level disputes that seem to make land issues so intractable in PNG?

\section{JOHN:}

Usually the village court magistrates would try to resolve such a dispute. It is not a land dispute per se, and therefore cannot come before the formal court system because the land is communally owned. It is only a difference of opinion between different members of the landowning clans with respect to which foreign investor they prefer. Unfortunately, it seems that even the village court magistrates are taking sides when dealing with such issues, as it really has got to do with the benefits that flow from the deal, which only adds to the problem. The land issue is always very sensitive and runs deep, with family ties and connections coming into play. We try to encourage the settlement of such disputes through the usual Melanesian ways, where everybody sits down 
together and talks through things. We believe that, if they resolve the dispute using their own traditional dispute resolution mechanisms, the result will stick. They will also honour it and will abide by it. If it is imposed on them, it might lead to further disputes.

\section{Another Cabinet Decision}

When Peter O'Neill presented the two final reports of the COI to the national parliament in September 2013, he declared that '[w]e will no longer watch on as foreign owned companies come in and con our landowners, chop down our forests and then take the proceeds offshore' (Nicholas 2013a). But what was he going to do about it? He initially undertook to establish a ministerial committee that would recommend an appropriate course of action within a period of two months (Nicholas 2013b), but when he tabled the reports in Parliament, he said that the Minister for Lands and Physical Planning would appoint a taskforce to design a new legal framework for the conversion of customary land into leasehold land (Nicholas 2013a). It was not clear whether these were meant to be two distinct initiatives, nor was there any indication of how the new legal framework might relate to the one that had come into effect at the start of the previous year.

Nothing more was heard of the committee or the taskforce until February 2014, when the Prime Minister told a radio audience that the committee would be chaired by the Forests Minister, Patrick Pruaitch, and the other members would be the Lands Minister, Benny Allan, and the Agriculture Minister, Tommy Tomscoll (Nicholas 2014). This news prompted the Eco-Forestry Forum to call for the removal of Pruaitch from the whole process on the grounds that putting him in charge of it would be like 'giving the keys of the blood bank to Dracula' (Act Now 2014b). It is not clear whether this observation was based on the belief that any forests minister would be reluctant to cancel forest clearing authorities or on the fact that two such permits had been allocated to agro-forestry projects in this minister's own electorate. In any case, it does not seem to have been a factor in O'Neill's subsequent decision to give Pruaitch the treasury portfolio and appoint Douglas Tomuriesa as the new Forests Minister. Tomuriesa convened a meeting of the Ministerial Committee in May 2014, and its recommendations formed the basis of a cabinet decision made in June (Act Now 2014c). 
On the question of how to rectify the previous abuse of the lease-leaseback scheme, there were three key elements to this decision:

- all SABLs that John Numapo and Nicholas Mirou had recommended for revocation were to be revoked;

- the Ministerial Committee was granted leave to make further recommendations on what should be done with SABLs on which Alois Jerewai had failed to report; and

- a Special SABL Taskforce was to be established under the Forests Ministry, reporting to the Ministerial Committee, with a remit to: (a) address matters raised by the findings of the COI; (b) implement recommendations of the COI; (c) investigate SABLs on which the COI made no recommendations; and (d) implement further decisions of the National Executive Council and the Ministerial Committee with regard to SABLs.

In order to ensure that such abuse could not be repeated:

- the Lands Department was directed to keep following the previous instruction not to grant any more SABLs, and the NFB was directed to keep following the previous instruction not to grant any more forest clearing authorities over areas covered by SABLs;

- the Land Act was to be amended to remove the provisions allowing for the grant of SABLs; and

- administration of the land group incorporation process was to be transferred from the Lands Department to the Investment Promotion Authority.

Despite the length of time that had elapsed since the Prime Minister promised to act on the COI's findings, this decision seemed at first sight to satisfy most of the demands that had been made by various members of the land grab policy network, including members of the anti-dependency group. 5 It may have fallen short of their demand for an immediate cancellation of all forest clearing authorities, but it still ignored an earlier ruling of the National Court that said the National Executive Council did not have the power to prevent the NFB from granting such permits

5 The decision to remove Sections 11 and 102 from the Land Act actually went beyond the recommendations contained in John Numapo's final report. 
in the first place. ${ }^{6}$ Tiffany Twivey (formerly Nonggor), who had been a member of the conservation policy community in her capacity as legal adviser to the Eco-Forestry Forum, but was now Peter O'Neill's legal adviser, welcomed the cabinet decision as a great victory for the people of PNG and proof of the Prime Minister's good faith (Act Now 2014d).

But then something strange happened. In July 2014, the Office of the Registrar of Titles in the Lands Department published notices in the national newspapers that summoned the 22 corporate entities holding 29 SABLs to return the original copies of their leases in compliance with the cabinet decision. Fourteen agro-forestry projects were affected by this order, but only three of these had forest clearing authorities that were still valid. ${ }^{7}$ Needless to say, the notices made no mention of the 26 leases on which Alois Jerewai had failed to report, but they also left out another 20 leases on which the other two commissioners had provided recommendations. Some of these 20 leases had already been invalidated in one way or another, and some of the smaller ones did not exhibit the sort of abuse that would warrant their cancellation, but eight of them were associated with major agro-forestry projects, and these eight leases should have been revoked if the cabinet decision was going to be implemented (see Table 8.1).

Table 8.1 Agro-forestry projects whose leases were recommended for revocation in June 2013 but were not listed for revocation in July 2014.

\begin{tabular}{|l|l|r|}
\hline Province & Project & SABL area (ha) \\
\hline Central & Abeda Integrated Agriculture & 11,700 \\
\hline Oro & Musa-Pongani Integrated Agro-Forest & 320,060 \\
\hline East Sepik & Angoram (Marienberg) Integrated Agriculture & 25,600 \\
\hline West Sepik & Aitape West Integrated Agriculture & 47,626 \\
\hline West Sepik & Bewani Oil Palm Development & 139,909 \\
\hline West Sepik & Nuku Integrated Agroforestry & 239,810 \\
\hline New Ireland & Danfu Integrated Agriculture & 24,581 \\
\hline New Ireland & Central New Hanover Integrated Agroforestry & 56,592 \\
\hline
\end{tabular}

Source: The National, 18 July 2014.

6 Musa Century Ltd v O'Neill [2013] PGNC 152. The case against the state had been mounted by the developers of the largest agro-forestry project in Oro Province. It is not clear whether this project has ever been granted a forest clearing authority.

7 Oddly enough, the list of leases to be surrendered included the one granted to Mekeo Hinterland Holdings Ltd, which had already been revoked by the National Court in 2010. 
It was not immediately obvious what these eight projects had in common that might explain their omission from the list. Six of them had been granted forest clearing authorities that were still valid, five were exporting logs in 2012, four were doing so in 2013, and three were still doing so in 2014. One of the two projects that exported logs in all three of those years was the Bewani project in West Sepik Province, but this project was sponsored by Belden Namah, and he was now an enemy of the Prime Minister. The other project that exported logs in all three years was the Central New Hanover project in New Ireland Province, but this project, like the Danfu project in the same province, was sponsored by a former Provincial Premier, Pedi Anis, whose influence over the relevant government ministers was equally tenuous. Perhaps some clue may be found in a statement attributed to the Prime Minister a few days after the cabinet decision, in which he said that 'those SABLs with genuine investors and genuine partnerships with the landowners should work through the Lands Department to acquire new leases to enable them to continue their projects' (Miae 2014), but this does not reflect the decision that was actually made. One might also speculate about the capacity of the various project sponsors or developers to influence the officials in the Lands Department who were responsible for making up the public notices, but one might equally suppose that the latter were guilty of that same negligence for which they had been taken to task by the commissioners. The Forests Minister was later quoted as saying that some SABLs were not revoked because of the amount of money already invested in their development (Tlozek 2015), but this point would hardly seem to apply to the two leases from which no logs had yet been extracted.

\section{The Twists and Turns of Turubu}

Another clue to the mystery surrounding the implementation of the cabinet decision may be found in the political and legal history of one big operational agro-forestry project whose SABL was included in the public notice issued by the Lands Department. This was the Wewak Turubu Integrated Agriculture Project, generally known as the Turubu project, which operates on a lease of more than 100,000 hectares in the vicinity of Wewak, the capital of East Sepik Province. This is one of several agroforestry projects, in various stages of development, that have generally 
been endorsed by local politicians, including the former Prime Minister, Michael Somare, as part of a grand plan to create what is sometimes called an 'economic corridor' running through the middle of the province. ${ }^{8}$

The Turubu project has been established on an SABL that was granted to a company called Sepik Oil Palm Plantation Ltd in 2008. This is actually a joint venture between a local landowner company called Limawo Holdings Ltd and a foreign investor called Wewak Agriculture Development Ltd. The project secured a forest clearing authority in 2009, and more than 400,000 cubic metres of logs were exported from the area over the following five years. Like the Sigite-Mukus project in East New Britain, this project has attracted a good deal of attention from members of the conservation policy community, first because the area is home to an eco-forestry project that has served as a conduit for protests by dissident landowners, and second because it has been claimed that the foreign investor is one of PNG's well-established logging companies. ${ }^{9}$ When Nicholas Mirou conducted his hearings in Wewak in February 2012, he was harassed and abused by supporters of the agro-forestry project because they thought he was secretly in league with the dissidents (Mirou 2013: 831-2).

It seems that two different groups of dissident landowners took legal action to get the SABL revoked by the National Court, the first in 2011, the second in 2012 (Sheila Sukwianomb, personal communication, December 2014). The first group obtained a restraining order to halt the logging operation in May 2012 (Matthias 2012), but it does not seem to have had much effect. It was the second group that eventually won its case in July 2014, when Justice Gavara-Nanu nullified the SABL on the grounds that it breached the provisions of the Land Act and the National Constitution. ${ }^{10}$ This judgement was delivered during the interval between

8 Much of the inspiration for this plan came from Sepik migrants who were involved in the development of the existing oil palm schemes in West New Britain.

9 The logging company in question is WTK Realty Ltd, which has held concessions in West Sepik Province for many years. Its purported link to Wewak Agriculture Development Corporation Ltd was first aired in the Greenpeace report, where the two companies were said to share a common address in Port Moresby (Winn 2012: 33). A more complex set of corporate connections was described in a subsequent report by Oxfam Australia, which aimed to hold Westpac Bank accountable for the Turubu project because of its financial relationship with WTK Realty Ltd (Oxfam 2014: 16). There is no firm evidence to substantiate these claims. The two companies have offices in Port Moresby that are close to each other but are not identical. The connections described in the Oxfam report are supposedly based on evidence provided to the COI, but the transcripts of the relevant hearings show that this evidence has been misinterpreted.

10 Maniwa v Malijiwi [2014] PGNC 25. 
the cabinet decision and the publication of the notices demanding the surrender of 29 leases, so it might perhaps explain why the Turubu lease was one of them. However, the judgement attracted no publicity at the time, and there is another plausible explanation for its inclusion.

One of the new entrants to the national parliament in 2012 was Richard Maru, who was elected to represent Yangoru-Saussia District in East Sepik Province. He had an interest in the Turubu project because the lease included part of his electorate, and he lost no time in voicing his suspicion that the developers were more interested in taking out the logs than putting in the oil palm (Anon. 2012). This initially led members of the anti-dependency group to hope that Richard Maru would be another champion of their cause, like Governor Gary Juffa, but they were soon disappointed, because it turned out that he was planning to develop another oil palm project in partnership with a different foreign investor. The focal point of this project, which is commonly known as the Sepik Plains project, would be a nucleus estate constructed on a fairly large portion of government land in his own electorate that should not have been included in the Turubu SABL because it had already been alienated by the Australian colonial administration (Anon. 2013). ${ }^{11}$ His own promise to cancel the SABL and give the rest of the land back to the customary landowners was thus connected with his plan for them to become smallholders producing raw material for the mill to be built by his own development partners. In his capacity as Minister for Trade and Industry, Maru was also able to secure a major grant from the Treasury to subsidise the development of his own scheme. So he could well have taken some pains to ensure that the Turubu lease would be cancelled by the Lands Department, regardless of what transpired in the National Court.

From a strictly legal point of view, the matter now got quite confusing. Limawo Holdings and its own development partner, Wewak Agriculture Development Ltd, lodged separate appeals to the Supreme Court to overturn the ruling of the National Court, while the landowner company teamed up with the East Sepik Provincial Government to launch a new

11 The greater part of the SABL area is located in the neighbouring electorate of Wewak. Jim Simatab, the member of parliament who has represented this electorate in most years since 2007, has been an enthusiastic supporter of the Turubu project. Simatab was the Parliamentary Secretary for Agriculture between 2007 and 2010, and was appointed as Minister for Correctional Services after the national elections of 2012. 
case in the National Court to overturn the cabinet decision, and the joint venture company, Sepik Oil Palm Plantation Ltd, did the same thing (Sheila Sukwianomb, personal communication, December 2014).

To the best of my knowledge, only one of these cases had been resolved by the end of 2015, but this was hardly a resolution. In May 2015, Justice Geita began hearing the case brought by the landowner company and the provincial government. Three months later, he ruled that the recommendations of the COI should not have formed the basis for a cabinet decision because the national government had failed to gazette an instrument that would extend the lifetime of the COI beyond March $2012 .{ }^{12} \mathrm{He}$ also ruled that it was unreasonable of the National Executive Council to include the Turubu lease in the list of 29 that were cancelled in June 2014 without considering the amount of capital already invested in the project. So he reinstated the lease. However, he was careful to say that his own ruling had nothing to do with any future rulings of the Supreme Court in respect of the appeals lodged against the previous ruling of the National Court that cancelled this lease on grounds that were unrelated to the recommendations of the COI. He was also careful to say that his ruling did not necessarily apply to the other 28 leases that the Lands Department had sought to cancel in the wake of the cabinet decision.

\section{Law, Politics and Ideology}

Two years after the COI's reports were made available to the public in November 2013, it was still impossible to see an end to the policy process from which it had emerged. It was unclear whether the national government would appeal to the Supreme Court to overturn Justice Geita's ruling, or simply wait to see what the Supreme Court did with the appeals that had already been lodged. The power of the National Executive Council to act on the findings of the COI was as uncertain as the real interest and intent of the ministers responsible for implementing its decisions. By the end of 2015, little more had been heard from the three members of the Ministerial Committee, except for an announcement by the Lands Minister, Benny Allan, that it would not be possible to cancel existing SABLs without enacting some new legislation that his departmental staff would draft 'as soon as possible' (Anon. 2015a).

12 Limawo Holdings Ltd v Numapo [2015] PGNC 155. 
The 'Special SABL Taskforce' seems to have been established at the end of 2014, but then became an 'SABL Implementation Taskforce' reporting directly to the head of the Prime Minister's Department (Anon. 2015b). The recommendations of this body were due to be submitted to the National Executive Council in October 2015, but they had not been made public by the end of that year. To judge by notices published in the National Gazette, officials in the Lands Department have not made any further attempt to grant additional SABLs under the current provisions of the Land Act, but there is no evidence that they have drafted amendments to the current legislation that would either get rid of those provisions or change the administration of the land group incorporation process.

For some members of the land grab policy network, the government's failure to take decisive action on this issue is not just a sign of legal complexity or bureaucratic incompetence but proof of systemic corruption at all levels of the political establishment. For members of the anti-dependency group, Gary Juffa, the Governor of Oro Province, is the only member of parliament who has shown that he really cares about the rights and interests of customary landowners, and the only public servants who have shown a comparable concern with the 'rule of law' are members of the judiciary, including John Numapo and Nicholas Mirou. If other politicians and public servants have been unable to avoid the pretence of sharing this concern, then that is only because a new popular front has been mobilised to remind them of their constitutional duties.

Of course, politicians are never immune to public opinion, especially in a country like PNG, where roughly half of the members of parliament have lost their seats at each successive national election. And there is no doubt that members of the anti-dependency group have done a fine job of maintaining a semblance of public outrage through every available medium of communication. In this respect, special credit must go to Effrey Dademo, the founder of an NGO called Act Now (sometimes with an exclamation mark), and Rosa Koian, the campaign manager for another NGO, the Bismarck Ramu Group, which was born out of the ruins of a conservation program funded by the Global Environment Facility in the 1990s (van Helden 2009). ${ }^{13}$ Effrey, in particular, has performed a valuable service for all members of the land grab policy network by not

13 Effrey and Rosa were two of the 18 members of the conservation policy community who received the email message in which Paul Barker called for a strategy to make landowners aware of the land grab issue back in January 2010 (see Chapter 6, this volume). 
only making regular posts to a dedicated section of the Act Now blog, but also harvesting and recycling information from every corner of the internet that serves to keep the scandal alive.

Effrey and Rosa were the primary authors of an 'open letter to the Prime Minister' that was published as an advertorial in one of the national newspapers in December 2013, shortly after the public release of the COI's final reports, but they wrote this on behalf of a group of 20 NGOs that formed the core of the anti-dependency group at that time (Act Now PNG and Bismarck Ramu Group 2013). The letter simply demanded that all the 'unlawful' leases must be revoked, the land covered by the leases must be returned to its customary owners, and all the 'illegal' forest clearing authorities must be cancelled. It also called for the COI's reports to be referred to yet another taskforce known as Task Force Sweep, an agency based in the Justice Department that had been established around the same time that the COI started its hearings, and had a mandate to investigate and prosecute cases of corrupt behaviour on the part of politicians and public servants. By the end of 2014, this body had lost the support of the Prime Minister because it had started to investigate his own behaviour, and it never did get around to investigating the abuse of the lease-leaseback scheme, but the call made by the antidependency group still had the effect of aligning the campaign against the land grab with a broader campaign supported by people whose concern with political corruption was not simply a function of their opposition to all forms of large-scale resource development. That is how organisations like Transparency International and Global Witness became part of the reconstructed land grab policy network, almost as if they were occupants of the space vacated by the climate policy group (see Chapter 6, this volume).

Some of the demands made by members of the network since the release of the COI's findings have been somewhat misguided. For example, it is hard to justify the claim that there is anything technically 'illegal' about the grant of forest clearing authorities, and equally hard to see how these could simply be cancelled by the NFB without creating a legal liability to compensate the holders of such permits. As we have seen, the Board has sometimes suspended the permits of companies that failed to comply with their permit conditions, and it does not seem to have granted any new permits until the National Court ruled that the moratorium imposed 
by the National Executive Council was itself illegal. ${ }^{14}$ In October 2014, Act Now teamed up with Transparency International and another local NGO to complain about the Board's decision to renew the forest clearing authority that had been granted to the Sigite-Mukus project four years previously, but were told by forestry officials that nothing could be done so long as the leasehold arrangements were still in effect and the permitholder had complied with the conditions of its permit (Act Now 2014e). The forest clearing authority that had been granted to Albright Ltd in 2009 does seem to have lapsed when the National Court subsequently nullified the SABL that had been issued to the landowner company, Mekeo Hinterland Holdings Ltd. But if the government had been successful in its defence against Albright's claim for damages as a result of this ruling, that does not mean that it could have defended the breach of a contract in which it did have an 'actionable statutory duty' towards the other party, so if the lease had not been nullified, and the sublease was therefore still valid, then cancellation of the clearance permit would have been a risky move.

A second example of false hope is contained in the demand for Task Force Sweep or other organs of the state to prosecute those individuals whose corrupt and illegal behaviour was documented by the COI. The COI's terms of reference did not really allow for an investigation of the chains of influence or command by which politicians got public servants to evade or ignore the procedures that should have established the consent of customary landowners to the alienation of their land. The commissioners found little evidence of bribery, and they made no specific recommendations for the prosecution of the various lands officers and other public servants whose negligence or incompetence was the focus of their investigation. Furthermore, as they often pointed out in the conduct of their hearings, evidence presented to a commission of inquiry cannot later be used as the basis for a criminal conviction, so prosecutions would have to be based on fresh detective work by the police. And finally, the sort of evidence that might be used to convict someone of 'stealing

14 Musa Century Ltd v Peter O'Neill and Others [2013]. PNG National Court judgement N5334, 23 August. An 'unidentified source' has been cited as the basis for a claim that the Board granted a new forest clearing authority over 105,000 hectares of land held under an SABL in West Sepik Province in April 2014 (Global Witness 2014: 3). This would appear to be the Wammy project, from which a substantial quantity of logs was exported in 2015 (see Table 7.2, Chapter 7, this volume). 
customary land' is actually much harder to assemble than the sort of evidence that Task Force Sweep or the Public Prosecutor has used to convict people of stealing public money.

If it is also unreasonable to expect the government to rapidly concoct some new piece of legislation that would instantly nullify an entire collection of leases and licences without risking a new round of litigation on the part of their current owners, it is certainly not unreasonable to ask the question posed by Gary Juffa, which is why government ministers, provincial governors, or other members of parliament have not been helping specific groups of landowners to take legal action in defence of their own property rights. There are now several cases in which the National Court has nullified an SABL on the grounds that some landowners did not consent to it, and none of these judgements has so far been overruled on appeal to the Supreme Court. If the COI and the media campaign have served to enlarge the population of landowners who have just cause for complaint about the loss of their property, why would their elected political leaders not seek to enhance their chances of re-election by helping to retrieve it?

Many members of the anti-dependency group, or the anti-corruption group, think the answer lies in the subordination of these political leaders to foreign business interests. From this assumption it follows that their complacency about the land grab is an affront to nationalist sentiment, as well as to the 'ideology of landownership' that counts every indigenous citizen as a customary landowner who should be rightly jealous of his or her property. But this argument barely makes sense of a political system in which most members of parliament represent electorates in which most of the voters are customary landowners living on their own land, unless it is also assumed that the foreign companies supply the money with which the politicians buy the votes of the people whose land they have conspired to steal.

An alternative explanation can be found in the testimonies that the COI itself collected from the landowners who had an interest in each of the areas covered by its hearings. The majority of the witnesses who objected to the grant of an SABL said that they were not motivated by opposition to whatever form of large-scale resource development had supposedly justified the creation of this new property right, but rather by their exclusion from the decision-making process by which a landowner company had been formed or a foreign investor had been found. In many cases, different landowner companies, or different factions represented on the board of one landowner company, had formed partnerships with 
different investors, each one with a view to convincing their partners that they alone were the genuine representatives of all the customary owners of the land to be developed. Members of the anti-dependency group have construed this form competition as evidence that foreign investors use local intermediaries who often mislead people and use payments in cash or presents to secure consent', while some of these intermediaries 'made deals with foreign companies on land that was not theirs and was actually used by other communities' (Mousseau 2013: 25). However, those investors who appeared before the COI often appeared to be truly confused by the politics of landowner representation, and there is other evidence to indicate that many potential investors have given up and gone home when they could not see a way to manage this sort of political risk. ${ }^{15}$

Regardless of the power dynamics of this form of partnership and competition, what matters here is that politicians who aspire to be elected or re-elected as members of the national parliament or as presidents of locallevel governments may rationally calculate that there are more votes to be gained from promising some form of large-scale resource development than from opposing any form of large-scale resource development on the customary land of their constituents. This certainly seems to be the case in some of the provinces where large areas of customary land have been alienated through the lease-leaseback scheme. When the COI had just started to conduct its hearings, Leo Dion declared that there was no need for any inquiry to be conducted in East New Britain Province, of which he was then the Governor, ${ }^{16}$ because agro-forestry projects initiated under the lease-leaseback scheme had broad popular support and exemplified the 'public-private partnerships' that were an integral component of the provincial government's development strategy (Anon. 2011). All of the elected political leaders of that province have consistently toed the same line, so it is not surprising that they have failed to back any legal action taken by groups of dissident landowners who want to get their land back. Indeed, the Prime Minister may have cause to be relieved that East New Britain was one of the three provinces covered in the hearings conducted by Alois Jerewai, so its agro-forestry projects have been saved from any immediate threat to the integrity of their land titles.

15 This is a classic example of what economists call the principal-agent problem. The landowners end up with developers who cannot be trusted to produce 'real development' because the landowner representatives cannot be trusted to represent the 'true landowners'.

16 He was appointed Deputy Prime Minister and Minister for Inter-Governmental Relations after the national elections of 2012. 
Most members of PNG's national parliament would claim to be customary owners of land in their own electorates. Most of the voters in most electorates reside on what they think is still their customary land, even if the law says that it has been alienated. Only a minority of these electorates contain large areas of customary land that have been legally alienated through the lease-leaseback scheme. But most of the members who represent these electorates believe that their own political fortunes are tied to the promise that these areas will be 'developed', and most of the members who represent other electorates, where this form of alienation has not taken place, appear to share the same belief. But all members would still profess to share Gary Juffa's concern for the rights and interests of customary landowners, since these are the people who constitute the nation.

A grand narrative of bribery and corruption does not really serve to explain this combination of phenomena. If it is unrealistic to portray the land grab policy network as a single community of interest with a common policy objective, it may also be unrealistic to portray the state as an overbearing, monolithic, corrupt and incompetent vehicle for the implementation of a neoliberal policy agenda (Lattas 2011). We need to bear in mind that national government ministers who previously pronounced their public support for the alienation of so many large areas of customary land commonly justified this process by reference to a 'developmental' agenda conceived as a nationalist alternative to the 'neoliberal' policy prescriptions of the World Bank. And in the aftermath of the COI, members of the anti-dependency group have quite correctly asked why a government that is still committed to the same agenda could possibly be expected to halt or reverse the process of expropriation by which it has been implemented. Politicians still talk up the prospects of 'economic corridors', 'special economic zones', 'impact projects' and 'public-private partnerships' in their electorates, but the neoliberal connotations of such terms are given another meaning in the networks of patronage through which they harvest the votes of customary landowners who expect their own leaders to deliver developers to their land. So what seems to be at work here is a contradiction between the ideology of landownership and an ideology of rural or national development that cannot be resolved at any level of political organisation, yet still constitutes a quite distinctive form of political behaviour. 


\section{Conclusion}

As noted in Chapter 6, the original reason for allowing customary landowners to lease their land to the state and have it leased back to a corporate body of their own choice was the absence of a legal mechanism for the direct registration of customary land titles. That hole in the policy framework has since been plugged with amendments to the Land Registration Act and the Land Groups Incorporation Act. What seems to have bothered John Numapo (and a number of other people) is that these laws may prove to be unworkable, or may only serve to 'mobilise' relatively small areas of customary land. When John said that SABLs should still be the mechanism of choice for what he called 'high-impact' projects needing large amounts of rural land, he had not forgotten the ambitious land mobilisation targets set by the Somare government in a number of policy and planning documents between 2002 and 2011. Richard Maru's solution to this problem, which is to use a large block of public land to form the core of a new rural development project, resembles the policy adopted by the Australian colonial administration when it established the first big oil palm scheme in the 1960s. However, this solution has only limited scope for replication today, not only because of the concentration of such blocks in a narrow coastal belt where they were previously alienated for the development of copra plantations during the colonial period, but also because these blocks are subject to multiple claims of customary ownership that have only grown stronger with the passage of time (Filer 2014).

In the first two years after the new legislation was certified and gazetted, about 15,000 hectares of land had apparently been registered in the names of incorporated land groups, but one of the 11 titles whose registration was advertised in the National Gazette accounted for more than two thirds of this land area. More disturbing was a notice published in August 2014, which said that the Lands Department was intending to accept a land investigation report that would establish the ownership of the whole of one local-level government area (more than 470,000 hectares of land) by three incorporated land groups. This example suggests that the problem of consent is not simply solved by insisting that properly constituted land groups be the only legal entities allowed to sublease customary land to private investors, especially if the Lands Department is the arbiter of what constitutes a proper constitution. In this respect, it should be noted 
that 10 SABLs over areas larger than 10,000 hectares were granted to incorporated land groups before the Commission was established, none of these covered an area larger than 50,000 hectares, all of them look quite suspicious, but only two came to the attention of the Commission.

The size of a block of land is not the only consideration here. One of the SABLs that was investigated by the Commission, and was included in the list of 29 leases that the Lands Department tried to recall in July 2014 , covered an area of roughly 25 hectares in the national capital, Port Moresby. Within a month of the publication of the notice of revocation, representatives of one local clan were complaining that officers of the Lands Department had certified the reincorporation of the clan that was implicated in the SABL without providing the legally required opportunity for objections to be made to its original claim to customary ownership of the land in question (Anon. 2014). ${ }^{17}$ This is one of several cases in the national capital which suggest that the capacity of some people to appropriate customary land claimed by other people is not so much a function of the land area in question as of the value of the economic benefits to be obtained from its development.

The recommendations of the Commission left open the possibility that land groups already involved in the grant of an SABL could reincorporate themselves under the terms of the amended legislation, register titles to their land, and then grant fresh subleases to investors of their choice. However, the operators of PNG's existing oil palm schemes, who hold a number of subleases under SABLs previously granted to incorporated land groups, have already discovered that this is likely to be a painfully slow process unless the participants, including officers of the Lands Department, are willing and able to bend or break the law. That is why John Numapo, as a member of the land development group in the land grab policy network, doubts the capacity of the new legislation to solve the problem of development, and that is why members of the antidependency group consider the new legislation as a mask for the real problem of corruption (Act Now 2014f). The events that have followed the public release of the Commission's findings suggest an additional conclusion: that appeals to the 'rule of law', whether in the form of legislation, litigation or adjudication, will not suffice to settle the contest

17 This is one of the SABLs in which Rimbunan Hijau has an economic interest, but it has nothing to do with the practice of agro-forestry. 
between the ideologies of landownership and development that is still being played out at every level of political organisation, from the level of the nation-state to the level of the rural or urban council ward.

\section{References}

Act Now (for a better Papua New Guinea), 2014a. 'Land-Lease Overhaul Needed: PNG Land Scandal Commissioner.' Blogpost by 'rait man', 14 February 2014. Viewed 12 October 2016 at: www.actnowpng.org/ content/land-lease-overhaul-needed-png-land-scandal-commissioner.

_ 2014b. 'Call to Replace SABL Review Team Chairman.' Blogpost by 'rait man', 1 March. Viewed 12 October 2016 at: www.actnowpng. $\mathrm{org} /$ content/call-replace-sabl-review-team-chairman.

— $2014 \mathrm{c}$. 'The Full NEC Decision on the SABL Land Grab.' Blogpost by 'rait man', 27 June. Viewed 12 October 2016 at: www.actnowpng. org/content/full-nec-decision-sabl-land-grab.

—, 2014d. 'PMs Lawyer Joy over SABL Scrapping.' Blogpost by 'Elizabeth1', 20 June. Viewed 12 October 2016 at: www.actnowpng. org/content/pms-lawyer-joy-over-sabl-scrapping.

_ 2014e. 'Forest Authority Not Stopping Illegal Logging in SABL Areas.' Blogpost by 'Effrey', 21 October. Viewed 12 October 2016 at: www.actnowpng.org/blog/forest-authority-not-stopping-illegallogging-sabl-areas.

—, 2014f. 'New Land Laws Premature-Government Must Deal with Corruption First.' Blogpost by 'Effrey', 29 October. Viewed 12 October 2016 at: www.actnowpng.org/blog/new-land-lawspremature-government-must-deal-corruption-first.

Act Now PNG and Bismarck Ramu Group, 2013. 'SABL Land Grab: An Open Letter to the Prime Minister.' Post-Courier, 5 December.

Anon., 2011. 'Dion Wants ENB to Be Excluded from SABL Inquiry.' Post-Courier, 1 September.

— 2012. 'Maru Unhappy with Progress of Projects.' The National, 20 September. 
__, 2013. 'Landowner Disappointed.' The National, 27 December.

__, 2014. 'Clan Land Row Brewing.' The National, 8 August.

___, 2015a. 'Govt Plans to Cancel SABLs.' The National, 11 August.

__, 2015b. 'SABL Final Report Set to Go before Cabinet.' Post-Courier, 5 October.

Filer, C., 2014. 'The Double Movement of Immovable Property Rights in Papua New Guinea.' Journal of Pacific History 49: 76-94. doi.org/1 $0.1080 / 00223344.2013 .876158$.

Global Witness, 2014. 'The People and Forests of Papua New Guinea under Threat: The Government's Failed Response to the Largest Land Grab in Modern History.' London: Global Witness.

GoPNG (Government of Papua New Guinea), 2007. The National Land Development Taskforce Report: Land Administration, Land Dispute Settlement, and Customary Land Development. Port Moresby: National Research Institute (Monograph 39).

Lattas, A., 2011. 'Logging, Violence and Pleasure: Neoliberalism, Civil Society and Corporate Governance in West New Britain.' Oceania 81: 88-107. doi.org/10.1002/j.1834-4461.2011.tb00095.x.

Mathias, A., 2012. 'Court Restrains Logging on Local Land.' The National, 22 May.

Miae, E., 2014. 'State Cancels All SABLs Obtained Illegally.' The National, 19 June.

Mirou, N., 2013. Commission of Inquiry into Special Agriculture and Business Lease (C.O.I. SABL): Report. Port Moresby: Government of Papua New Guinea. Viewed 5 October 2016 at: www.coi.gov.pg/ documents/COI\%20SABL/Mirou\%20SABL\%20Final\%20Report.pdf.

Mousseau, F., 2013. 'On Our Land: Modern Land Grabs Reversing Independence in Papua New Guinea.' Oakland (CA): The Oakland Institute in collaboration with Pacific Network on Globalisation.

Nicholas, I., 2013a. 'O’Neill: SABL Success Rates Appalling.' Post-Courier, 19 September.

__, 2013b. 'Trio Referred.' Post-Courier, 13 September. 
—, 2014 . 'Govt to Cancel SABLs Obtained Illegally.' Post-Courier, 7 February.

Numapo, J., 2013. Commission of Inquiry into the Special Agriculture and Business Lease (SABL): Final Report. Port Moresby: Government of Papua New Guinea. Viewed 5 October 2016 at: www.coi.gov. pg/documents/COI\%20SABL/Numapo\%20SABL\%20Final\%20 Report.pdf.

Oxfam, 2014. 'Banking on Shaky Ground: Australia’s Big Four Banks and Land Grabs.' Carlton (VA): Oxfam Australia.

Tlozek, E., 2015. 'PNG in No Rush to Crack Down on Asian Logging Giants.' $A B C$ News, 12 November.

van Helden, F., 2009. “"The Report Was Written for Money to Come”: Constructing and Reconstructing the Case for Conservation in Papua New Guinea.' In J.G. Carrier and P. West (eds), Virtualism, Governance and Practice: Vision and Execution in Environmental Conservation. New York: Berghahn Books.

Winn, P., 2012. 'Up for Grabs: Millions of Hectares of Customary Land in PNG Stolen for Logging.' Sydney: Greenpeace Australia Pacific. 
This text is taken from Kastom, property and ideology: Land transformations in Melanesia, edited by Siobhan McDonnell, Matthew Allen and Colin Filer, published 2017 by ANU Press, The Australian National University, Canberra, Australia. 